\title{
THE PRIORITY MEASURES ON THE RESTORATION OF STALINGRAD REGION AFTER THE END OF THE BATTLE ON THE VOLGA ${ }^{1}$
}

\author{
Olesya A. Gomanenko \\ Volgograd State University, Volgograd, Russian Federation
}

\begin{abstract}
This paper is devoted to the study of the Stalingrad Group of Troops. That military division was created after the end of the Battle of Stalingrad. The the Group's creation was aimed at rest and training of the soldiers and officers who had left bloody battles to prepare them for the further military operations. For the first time in the Great Patriotic War the Group faced the practical challenge to help the civil authorities and administration to restore the economy and infrastructure of the region including the network of river lines, railways and highways. The Stalingrad Group of Troops had to carry out mine clearing of the area of military operations, to participate in collecting trophies, burial of the remains of fallen soldiers. Process of mine clearing was assigned to engineering parts of the 62nd, 64th, 66th armies. Four engineering and mine crews, two specialized battalions and one company, staff of Osoaviakhim, Management of People's Commissariat for Internal Affairs were connected. The volume of the required works was considerable. The special plan was prepared, the territory was differentiated, terms were determined. During interrogations new developments of the German designers - mines, radio-controlled from Hamburg, and the jumping mines were found. Work on mine clearing of the district and collecting explosive objects continued during the whole reconstruction period. Activity of the Stalingrad Group of Troops allowed earlier beginning of the main reconstruction work in the city and the region.

Key words: Great Patriotic War, Battle of Stalingrad, Stalingrad Group of Troops, restoration, transport, mine clearing, enginering units.

Citation. Gomanenko O.A. The Priority Measures on the Restoration of Stalingrad Region after the End of the Battle on the Volga. Vestnik Volgogradskogo gosudarstvennogo universiteta. Seriya 4, Istoriya. Regionovedenie. Mezhdunarodnye otnosheniya [Science Journal of Volgograd State University. History. Area Studies. International Relations], 2018, vol. 23, no. 1, pp. 116-125. (in Russian). DOI: https://doi.org/10.15688/ jvolsu4.2018.1.11
\end{abstract}

УДК 94(470.45)"20":623.959.3

Дата поступления статьи: 12.09.2017

ББК 63.3(2)622-9

Дата принятия статьи: 21.11.2017

\section{ПЕРВООЧЕРЕДНЫЕ МЕРОПРИЯТИЯ ПО ВОССТАНОВЛЕНИЮ СТАЛИНГРАДА И ОБЛАСТИ ПОСЛЕ ОКОНЧАНИЯ СРАЖЕНИЯ НА ВОЛГЕ ${ }^{1}$}

\section{Олеся Александровна Гоманенко}

Волгоградский государственный университет, г. Волгоград, Российская Федерация

\footnotetext{
Аннотация. Данная статья посвящена исследованию деятельности Сталинградской группы войск. Это воинское образование сформировано после окончания Сталинградской битвы с целью отдыха и подготовки солдат и офицеров, вышедших из кровопролитных сражений, к дальнейшим боевым действиям. Также перед Сталинградской группой войск впервые в практике Великой Отечественной войны были поставлены задачи помощи гражданским органам власти и управления в восстановлении хозяйства и инфраструктуры региона, в том числе сети речных, железнодорожных и автомобильных дорог. Сталинградская группа войск обязывалась провести разминирование района боевых действий, участвовать в сборе трофеев, захоронении останков павших. Процесс разминирования возлагался на инженерные части 62, 64, 66-й армий, подключались четыре инженерно-минные бригады, два специализированных батальона и одна рота, сотрудники Осоавиахима, Управления НКВД. Объем требуемых работ был значителен. Был подготовлен специальный план, разграничена территория, определены сроки. В ходе допросов были обнаружены новые разработки немецких конструкторов - радиоуправляемые из Гамбур-
} 
га мины и прыгающие мины. Работа по разминированию местности и сбору взрывоопасных предметов продолжалась практически весь восстановительный период. Деятельность Сталинградской группы войск позволила начать в более ранние сроки основные восстановительные работы в самом городе и области.

Ключевые слова: Великая Отечественная война, Сталинградская битва, Сталинградская группа войск, восстановление, транспорт, разминирование, инженерные части.

Цитирование. Гоманенко О. А. Первоочередные мероприятия по восстановлению Сталинграда и области после окончания сражения на Волге // Вестник Волгоградского государственного университета. Серия 4, История. Регионоведение. Международные отношения. - 2018. - Т. 23, № 1. - С. 116-125. - DOI: https:// doi.org/10.15688/jvolsu4.2018.1.11

В дни 75-летия празднования победы под Сталинградом актуальным становится исследование малоизученных страниц сражения на Волге и процесса восстановления народного хозяйства и инфраструктуры города и области. Одной из таких страниц является деятельность созданной 5 февраля 1943 г. Ставкой Верховного Главнокомандования Сталинградской группы войск (СГВ). Политическая и экономическая ситуация, сложившаяся в СССР в начале 1943 г., настоятельно требовала максимального использования Советским государством уже имеющихся или потенциальных возможностей для отражения агрессии немецко-фашистских войск. В связи с данными обстоятельствами вопрос о быстрейшем восстановлении Сталинграда, являвшегося в предвоенный период и на начальном этапе войны одним из крупных промышленных центров Советского Союза, стоял очень остро. Однако механизм проведения восстановительных работ такого масштаба, как в Сталинграде, еще не был разработан. Именно Сталинградский регион стал первой экспериментальной площадкой, где пошагово разрабатывались и апробировались формы и методы возрождения освобождаемых территорий в условиях продолжавшихся активных боевых действий Красной Армии.

Источниковой базой настоящей статьи стали как опубликованные, так и неиздававшиеся архивные материалы. На современном этапе в связи с постепенным процессом рассекречивания фондов центральных и местных государственных архивов ученые получили доступ к новой информации. Это позволило начать продуктивный разговор об источниках рабочей силы и более четко вычленить этапы организации и проведения восстановительных мероприятий в Сталинграде и области. В этой связи значительным шагом стал сбор- ник документов о Сталинградской группе войск под редакцией профессора М.М. Загорулько [21]. В сборнике представлены материалы Российского государственного архива социально-политической истории (личного фонда Г.М. Маленкова), Центрального архива Министерства обороны РФ (Ставки Верховного Главнокомандования, Главвоенуправления Красной Армии, Сталинградской группы войск, 62-й и 64-й армий, 273-й стрелковой дивизии), Центра документации новейшей истории Волгоградской области (Сталинградского городского комитета обороны, обкома и горкома ВКП(б)), Государственного музеяпанорамы «Сталинградская битва». Во вступительной статье кратко охарактеризована разноплановая деятельность СГВ по восстановлению Сталинграда и области по материалам фондов Российского государственного архива экономики, Государственного архива Волгоградской области, Центра документации новейшей истории Волгоградской области.

Историография проблемы восстановления разрушенного войной хозяйства обширна. Много внимания уделялось общим мероприятиям государственных органов, вкладу различных социальных групп, отдельным отраслям народного хозяйства. Так, известный советский экономист Я.Е. Чадаев проанализировал развитие экономики СССР в годы Великой Отечественной войны в целом, констатируя факты вступления в строй вновь отстроенных предприятий ранее оккупированных территорий [23]. Региональные исследования также либо охватывали проблему в общем, либо отражали конкретный вопрос восстановительного процесса. Показательны работы С.П. Люшина, в которых автор раскрывал ход и результаты восстановления Сталинграда с 1943 по 1953 г. [14; 15]. Э.В. Кузьмина рассмотрела механизм финансирования восстановительных 
работ в тот же период [13]. В трудах Н.В. Кузнецовой отражены социально-экономические проблемы послевоенного возрождения Нижнего Поволжья $[11 ; 12]$. О.А. Гоманенко затрагивала вопросы восстановления народного хозяйства после завершения Сталинградской битвы, в частности, волжской речной инфраструктуры [5; 7]. Некоторые вопросы возрождения Сталинградской области отразились в коллективном труде по истории г. Сталинграда и области в 1937-1953 гг. [10]. Однако вопрос переформирования воинских соединений после крупных сражений и их участие в восстановительных мероприятиях в литературе не рассматривался.

До настоящего времени упоминания о Сталинградской группе войск в историографии крайне отрывочны. Вклад СГВ в возрождение региона на подготовительном этапе восстановительных работ комплексно не оценен. Это способствует формированию определенных информационных пустот, затрудняет исторический и экономический анализ масштабов и механизма восстановления Сталинграда и области. Задачей данной работы стало изучение деятельности СГВ по разминированию и разграждению территории региона, без чего нельзя было не только начать строительно-восстановительные мероприятия, но и возвращать гражданское население на прежнее место жительства.

Согласно директиве Ставки Верховного Главнокомандования № 46053 с 6 по 24 февраля 1943 г. командование СГВ было возложено на генерал-лейтенанта К.П. Трубникова. С 24 февраля командующим был назначен генерал-лейтенант В.В. Косякин, который и оставался им до последнего дня существования Группы. Штаб СГВ дислоцировался в г. Красноармейск Сталинградской области [21, с. $16-$ $17,34]$. По акту приема-передачи войсковых соединений, отдельных частей и учреждений СГВ от 24 февраля, численность всех боевых подразделений составляла 226232 тыс. человек. Позже выявлены и приняты на учет двадцать пять соединений и частей, не имеющих прямой войсковой подчиненности. К концу марта общее количество людей, входивших в состав СГВ, насчитывало 401904 человека. Дополнительно были приписаны к Группе военнообязанные, годные к службе в армии и к физическому труду, военнослужащие, находившиеся в госпиталях, бывшие советские военнопленные немецких концлагерей [21, с. 92-94].

За дни кровопролитных боев Сталинград и оккупированные немецко-фашистскими войсками районы области понесли существенный ущерб. Люди готовы были сразу же после освобождения налаживать мирную жизнь. Этому мешали оставшиеся после сражений советские и немецкие минные поля, подрывные сюрпризы, неразорвавшиеся снаряды, авиабомбы и гранаты. Кроме того, требовалась и санитарная очистка территории области, так как после боевых действий осталось огромное количество трупов [17]. Трудовые резервы области справиться с такими последствиями Сталинградской битвы не могли. Специалисты Осоавиахима в период с 15 января по 1 марта 1943 г. произвели только разминирование на участках: левый берег р. Царицы, пос. Купоросный, p. Царица в направлении оврага Дубовая Балка, берега р. Волги от ул. им. КИМ до ул. им. Огарева, завод им. Сакко и Ванцетти, деревообрабатывающий завод № 3, частично площадь им. 9 Января, Трамвайный парк, взвоз, ул. Козловская, Академическая, Социалистическая, Молотова, Баррикадная, Рабоче-Крестьянская, Республиканская, Исполкомовская, Ленина, Пугачевская. Всего было обезврежено 330 мин [8, л. 27]. Темпы разминирования в связи с нехваткой квалифицированных кадров были медленными. С января по июнь 1943 г. проходила подготовка специалистов по разминированию [4]. За месяц Осоавиахимовские организации обучали в среднем 70 специалистов-минеров. К тому же, согласно справке, подготовленной для Сталинградского городского комитета обороны, на 1 марта 1943 г. годных к мобилизации на промышленные предприятия и стройки в области осталось 12087 человек [19, л. 8]. Количество городских жителей в феврале составляло 32182 человека, главным образом женщин, детей, лиц преклонного возраста, хотя отмечался постоянный рост населения Сталинграда, например, в марте уже числилось 56 тыс. человек, в мае - 107 тыс. [13, c. 41]. Следует отметить, что с населением проводилась разъяснительная работа о правилах обращения со взрывоопасными предметами [9]. 
Областное и городское руководство собственными силами длительное время не смогло бы подготовить территорию к началу восстановительных мероприятий. Требовалось найти иной вариант проведения первичных подготовительных шагов. Поэтому с первого дня своего существования СГВ подключалась к процессу разминирования, уничтожения неразорвавшихся взрывоопасных предметов, сбору и вывозу трофейного имущества.

Разминирование Сталинграда и области осуществлялось силами инженерных частей 62-й армии генерал-лейтенанта В.И. Чуйкова, базировавшихся в районе пристани Сталинграда и Средней Ахтубы (начальник инженерных войск подполковник В.М. Ткаченко: 326-й армейский инженерный батальон под командованием капитана Козлова в составе 335 человек; 327-й армейский инженерный батальон под командованием старшего лейтенанта Каталицкого в составе 306 человек), 64-й армии генерал-лейтенанта М.С. Шумилова, располагавшихся в пос. Бекетовка г. Сталинграда (начальник инженерных войск генерал-майор В.И. Пляскин: 175, 330, 328, 329-й отдельные армейские инженерные батальоны в составе 1482 человек), 66-й армии генерал-лейтенанта А.С. Жадова, находившихся в пос. Пичуга и г. Дубовка Сталинградской области (начальник инженерных войск полковник Севостьянов: 431-й, 432-й армейские инженерные батальоны в составе 738 человек), 16-й инженерной бригады специального назначения Донского фронта подполковника М.Ф. Иоффе в составе 3315 человек (место расположения хут. Паньшино Сталинградской области), 57-й инженерно-саперной бригады РВГ подполковника А.Г. Загребина в составе 2041 человек (место расположения - г. Сталинград), 8-й инженерно-минной бригады подполковника В.Я. Владимирова в составе 2300 человек (место расположения - с. Заплавное Сталинградской области), 5-й инженерно-минной бригады подполковника В.Н. Столярова в составе 2300 человек (место расположения с. Красная Слобода Сталинградской области), 741-го минно-саперного батальона капитана П.В. Федоренко в составе 409 человек (место расположения - балка Воронцовка Сталинградской области), 14-го отдельного гвардейского батальона минеров подполковника Лю- банского в составе 249 человек (место расположения - хут. Паньшино Сталинградской области), 47-й отдельной инженерно-минной роты старшего лейтенанта Портного (место расположения - завод № 221 «Баррикады», г. Сталинград) [21, с. 32, 33, 43, 51, 56, 60, 63].

Суммарный состав специалистов инженерных подразделений Сталинградской группы войск составил на 24 февраля 1943 г. около 13500 человек, или $6 \%$ от общей численности Группы. Данные инженерные подразделения располагали 797 лошадьми, 501 автомашиной и 25 тракторами [21, с. 43, 51, 56, 60, 63]. Однако площадь подлежащей разминированию и разграждению территории области и города, а также значительный объем восстановительных работ требовали привлечения всех имеющихся людских сил. Для усиления инженерных частей СГВ использовались дивизионные саперные подразделения, из которых создавались маневренные команды численностью до 10 бойцов, автогужевые части, в том числе на волах и верблюдах (62-я и 64-я армии).

Командарм 62-й армии генерал-лейтенант В.И. Чуйков во исполнение директивы Ставки издал по армии Приказ № 025 от 11 февраля 1943 г., в котором сроки полного разграждения минных полей на заводах № 221 «Баррикады», «Красный Октябрь» и Нефтебазе устанавливались к 22 февраля. Руководил работами начальник инженерных войск подполковник В.М. Ткаченко. Это был первый официальный документ Группы по вопросу разминирования территории Сталинграда. И по этой причине не были учтены условия и особенности планирования мероприятий по разминированию, срок устанавливался произвольно и, как следствие, график его исполнения не мог быть соблюден. 15 февраля к решению возникших проблем был подключен чрезвычайный орган власти - Сталинградский городской комитет обороны, на заседании которого был составлен уточненный согласованный план и очередность разминирования объектов производства и инфраструктуры города [22, с. 488]. В распоряжение подполковника Ткаченко передавались минеры Сталинградского Осоавиахима, 31-й инженерно-химический батальон НКВД, подключались специалисты 24-го Управления оборонительного строительства [21, с. 25-26]. 
Основной приказ, регулирующий деятельность СГВ по данному направлению, был издан Наркоматом обороны СССР 22 февраля 1943 г. за № 0/780/ст: «О разминировании минных полей и ликвидации неразорвавшихся снарядов и авиабомб в г. Сталинграде и области». Для выполнения поставленных задач создан инженерный отдел СГВ во главе с генерал-майором Барановым. В документе определялись границы участков - от Бекетовки на юге Сталинграда, до Городища и Орловки на северо-западе, включались 6 островов по левому берегу Волги, а также поселки Красная Слобода, Нижне-Погромное. Сроки окончания работ устанавливались с 1 по 7 марта 1943 года. Ведущей силой назначались инженерные войска 62-й армии с подчинением им 5-й и 8-й армейских инженерно-минных бригад, а также специальных команд саперов и минеров из военнопленных общей численностью 500 человек, которых передавал в распоряжение СГВ начальник Управления лагерей капитан госбезопасности Н.Н. Смирнов [21, c. 29-30, 33-34].

Был разработан пошаговый механизм подготовки, организации и проведения мероприятий по снятию минных полей, подрывных сюрпризов и других взрывоопасных предметов на территории области. Он состоял из двух этапов. На первом устанавливался перечень советских и немецко-фашистских минных полей и заграждений, проверялась и уточнялась полученная информация. Этот объем работы реализовывали органы НКВД. Сталинградским УНКВД была создана специальная оперативная группа в количестве 7 человек для проведения допросов военнопленных офицеров и солдат армий вермахта, а переферийные отделы УНКВД опрашивали гражданское население, временно проживавшее в оккупированных районах [21, с. 33-34]. Всего было допрошено на 3 марта около 500 военнопленных и выявлено 59 минных полей с количеством мин от 20 до 3000 . До апреля 1943 г. работа на части установленных полей была по климатическим условиям невозможна, в связи с этим она началась после согласованных в плане сроков [21, с. 76].

Допросы дали не только фактический материал, были получены и важные данные о новых видах немецких мин и взрывателей.
Инженер-конструктор мин фирмы «Сименс и Гальске» Альфред Низзин, командированный в 1942 г. в Сталинград, рассказал об установке им и инженером Шульцем на СТЗ, заводах № 221 «Баррикады» и «Красный Октябры», кожевенном заводе, в районах станции Воропоново, города Калач радиоуправляемых из Гамбурга мин и прыгающих мин. Общее количество апробировавшихся под Сталинградом новых видов мин было свыше тысячи [21, с. 77].

Информацией А. Низзина заинтересовалось Главное военно-инженерное управление Красной Армии. Находившийся в начале марта в Сталинграде начальник ГВИУ генералмайор А.Я. Калягин и специальная группа из семи инженеров-конструкторов Инженерного комитета должны были на месте тщательно изучить материал о семи новых видах мин и трех взрывателях, однако Альфред Низзин заболел сыпным тифом и был помещен в госпиталь. Для предотвращения непредсказуемых последствий, которые могли причинить радиоуправляемые мины, их решено было обезвредить, не дожидаясь его выздоровления. Был выделен взвод из батальона специального минирования 16-й инженерной бригады специального назначения во главе с капитаном Рождественским, который и произвел разминирование. Одновременно шла забивка и прослушивание сигналов Гамбургской радиостанции [21, с. 78, 81].

На втором этапе организовывалось первичное обследование и разминирование территории, повторное контрольное разминирование и ликвидация неразорвавшихся снарядов, авиабомб, подрывных сюрпризов, изъятие взрывоопасных веществ. Эти работы обеспечивались документацией по минным полям, инструментом, телефонной и радиосвязью, автомашинами и гужевым транспортом, тягачами для траления мин; устанавливался порядок отчетности, обеспечивающий персональную ответственность каждого исполнителя за результаты [21, с. 33].

Повторное разминирование включало две проверки участков: первая проводилась силами 326-го и 327-го армейских инженерных батальонов 62-й армии, отдельными подразделениями 5-й и 8-й инженерно-минных бригад, 47-й отдельной инженерно-минной ротой. К вторичным контрольным обходам 
допускались специалисты УНКВД в количестве 180 человек и Осоавиахима. Эта процедура была крайне опасна, так как при первичном обследовании в помощь минерам была подготовлена карта установки мин, при повторном обходе они шли вслепую.

Следует отметить, что существовало дублирование функций контроля и надзора за ходом и результатами процесса разминирования. Проводившие разграждение воинские подразделения обязывались предоставлять отчетность ежедневно к 18 часам в оперативный штаб Приволжского военного округа подполковнику Александрову, а в свои части и штаб СГВ - к 19 часам [21, с. 32, 33]. Это мало способствовало слаженности руководства, возникали противоречия.

Масштабы разминирования Сталинградской области были колоссальными. Тем не менее потребности фронта диктовали срочное включение региона в выполнение государственных планов, первоначально как одного из узловых транспортных пунктов, затем как важнейшего промышленного центра. Сталинградская железная дорога только восстанавливалась, поэтому основной объем перевозок весной - летом 1943 г. лег на волжский речной флот. Навигация 1943 г. на Нижней Волге открылась 20 апреля, с опозданием в верхнем течении. В низовьях Волги движение началось гораздо раньше. Астраханский флот вступил в эксплуатацию с 4 апреля, 12 апреля из Астрахани вышли первые нефтекараваны. 14 апреля стала работать Сталинградская центральная переправа, а 17 апреля в Сталинград прибыл первый пароход с грузом и пассажирами $[6$, с. 57$]$.

В начале навигации 1943 г. Сталинградский порт (Сталинградская транзитная пристань) еще не действовал. Городские, волгодонской и лесные причалы порта были заминированы [20, с. 29-31], шла активная работа воинских подразделений и специалистов Осоавиахима, самих речников по снятию и обезвреживанию взрывоопасных предметов. Только в мае оказалось возможным приступить к расчистке территорий и подходов к пристаням от строительного и прочего мусора [3, л. 38 об.].

После первичного разминирования береговых объектов Пароходства, в основном про- веденного 326-м армейским инженерным батальоном 62-й армии, количество нефтекараванов и транспорта постепенно возрастало. Однако сама Волга силами Волжской военной флотилии еще длительное время продолжала освобождаться от минной опасности $[6$, с. 59].

Другой важнейшей задачей для региональных властей являлось скорейшее включение предприятий города в плановое хозяйство страны. Остро стоял вопрос разграждения территорий заводов и фабрик Сталинграда для обеспечения проходов строителей и возвращающихся из эвакуации рабочих к зданиям, производственным постройкам и участкам. Первоначально работы велись силами инженерных подразделений 62-й армии в северных районах, 64-й армии в южных районах, 57-й инженерно-саперной бригады и 47-й отдельной инженерно-минной роты СГВ в центре и на западных окраинах. После отбытия частей СГВ согласно постановлению Сталинградского городского комитета обороны от 26 июля 1943 г. командующий Сталинградским военным округом В.В. Косякин обязывался направить одно из подразделений по минно-разградительному делу на стройки Сталинграда [22, с. 593]. Также были созданы дежурные службы и посты из бойцов-минеров для разминирования и подрыва обнаруженных взрывоопасных устройств, работавшие по вызову предприятий [1, с. 45].

К 15 мая 1943 г. силами частей Сталинградской группы войск разминировано между Волгой и Доном 80 \% территории, за Доном $75 \%$. Здесь были обезврежены все советские минные поля, немецкие поля отработаны не полностью, часть не выявлена. Общая площадь проверенных участков 38000 кв. км, по актам сдано местным властям 35000 кв. км. Окончание работ планировалось к 15 июня. При проведении разминирования убито 97 человек, ранено 224 человека [21, с. 100].

Полностью весь комплекс мероприятий по разминированию территории не был выполнен СГВ. Мешали своевременному выполнению плана не только двоичность управления процессом, но и отсутствие должного количества квалифицированных кадров в воинских и специализированных частях. При этом остро стояла проблема подготовки кадров не только минеров, но и шоферов, трактористов, та- 
келажников, автогенщиков, водителей немецких тягачей. За период 1943-1944 гг. силами частей местной противовоздушной обороны, органов НКВД и трофейного управления бывшего Донского фронта (осталось в Сталинградской области после убытия воинских частей и расформирования СГВ) их было подготовлено 645 человек. Осоавиахим в 1943 г. подготовил более 250 специалистов-саперов [8, л. 27].

По актовым документам комиссий в составе представителей областного исполкома, комитета ВКП(б), инженерного отдела Сталинградского военного округа, Центрального совета Осоавиахима СССР, облвоенкомата, УНКВД, принимавших территорию области после разминирования, в 1944 г. общая площадь разминирования по сельским и городским районам области составила 5600 кв. км, разграждено 210 населенных пунктов, снято 92 минных поля [16, л. 2], в 1945 г. - общая площадь 305,2 кв. км, обезврежено 17 полей [18, л. 106, 108-108 об., 115, 119-119 об., 125125 об., 131-131 об., 137], в 1946 г. - площадь разминирования 1959 га, предварительной разведки - 755,5 га, контрольной проверки 12798 га [2, л. 6].

Таким, образом, работа по разминированию местности и сбору взрывоопасных предметов, как видно из вышесказанного, продолжалась практически весь восстановительный период. Тем не менее деятельность СГВ по разминированию Сталинградской области, несомненно, позволила начать в более ранние сроки основные восстановительные работы. Уже к 1 апреля 1943 г. они велись на предприятиях союзного значения - СТЗ, заводах № 221 «Баррикады», ЗКО, им. Сакко и Ванцетти, № 91 «Химпром», № 224 «Судоверфь», им. Петрова, гидролизном, Сталгрэсе и др. Город стал поставлять свою продукцию фронту. Сталинградская группа войск была расформирована 22 мая 1943 г. в связи с полным убытием войск бывшего Донского фронта на новые места дислокации. Офицеры и прикомандированные из центра генералы вернулись к исполнению основных должностных обязанностей.

\section{ПРИМЕЧАНИЕ}

1 Работа выполнена при финансовой поддержке Российского фонда фундаментальных иссле- дований и Администрации Волгоградской области, проект № 16-11-34006 «Сталинградская группа войск. 1943-1944 гг.».

\section{СПИСОК ЛИТЕРАТУРЫ}

1. Владимирова, Е. Д. Сталинградская группа войск: мероприятия по разминированию, 1943-1945 / Е. Д. Владимирова, Е. Л. Головина // Проблемы национальной безопасности России: уроки истории и вызовы современности. 25 лет без Советского Союза : материалы Междунар. науч.-просвет. конф., 27-31 мая 2016 г. - Краснодар : Традиция, 2016. - С. $44-48$.

2. Годовой отчет о работе взводов-минеров бывших в оккупации в районах области за 1946 г. // Государственный архив Волгоградской области (ГАВО). - Ф. 2129. - ОП. 3. - Д. 47.

3. Годовой отчет об эксплуатационной деятельности НВРП за 1943 г. // Российский государственный архив экономики (РГАЭ). - Ф. 9469. Оп. 6. - Д. 47.

4. Головина, Е. Л. Подготовка специалистов по разминированию полей и построек в январе июне 1943 года / Е. Л. Головина, О. А. Гоманенко, Б. Г. Усик // Военная история России: проблемы, поиски, решения : материалы III Междунар. науч. конф., посвящ. 160-летию окончания Крымской войны 1853-1856 гг., Волгоград, 23-24 сент. 2016 г. В 2 ч. Ч. 2. - Волгоград : Изд-во ВолГУ, 2016. - С. 54-63.

5. Гоманенко, О. А. Восстановление материально-технической базы речной инфраструктуры Нижней Волги в 1943 году / О. А. Гоманенко // Экономическая история России: проблемы, поиски, решения : ежегодник. - Вып. 10. - М. ; Волгоград : Изд-во ВолГУ, 2008. - С. 65-70.

6. Гоманенко, О. А. Минная опасность на Нижней Волге в навигацию 1943 года / О. А. Гоманенко, О. Ю. Редькина // Проблемы национальной безопасности России: уроки истории и вызовы современности. 25 лет без Советского Союза : материалы Междунар. науч.-просвет. конф., 27-31 мая 2016 г. - Краснодар : Традиция, 2016. - С. 56-60.

7. Гоманенко, О. А. Нижневолжское речное пароходство в 1943 г. / О. А. Гоманенко // Экономическая история России: проблемы, поиски, решения : ежегодник. - Вып. 7. - М. ; Волгоград : Изд-во ВолГУ, 2005. - С. 91-95.

8. Докладные записки о формировании, состоянии оперативно-служебной и боевой деятельности истребительного батальона Иловатского района, 1941-1944 гг. // ГАВО. - Ф. 773. - Оп. 1. - Д. 31.

9. Загорулько, М. М. Разъяснительная работа с населением Сталинградской области о правилах обращения со взрывоопасными предметами в 
1943 году / М. М. Загорулько, О. А. Гоманенко, Е. Д. Владимирова // Память и время: влияние войн и вооруженных конфликтов ХХ в. на Российское общество : сб. ст. Междунар. науч.-практ. конф. (г. Новороссийск, 12-15 сент. 2016 г.). - Пенза : Изд-во ПГУ, 2016. - С. 189-190.

10. История г. Сталинграда и области в $1937-$ 1953 гг. : Материалы к факультативному курсу. Волгоград : Волгогр. науч. изд-во, 2008. - 205 с.

11. Кузнецова, Н .В. Восстановление жилого фонда Сталинграда в 1943-1945 годах / Н. В. Кузнецова // Вестник Волгоградского государственного университета. Серия 4, История. Регионоведение. Международные отношения. - 2003. - Вып. 8. C. 12-19.

12. Кузнецова, Н. В. Нижнее Поволжье в 1945 1953 гг.: социальные проблемы послевоенного восстановления и развития / Н. В. Кузнецова. - Волгоград : Волгогр. науч. изд-во, 2010. - 220 с.

13. Кузьмина, Э. В. Восстановление Сталинграда : 1943-1950 / Э. В. Кузьмина. - Волгоград : Издатель, 2002. - 141 с.

14. Люшин, С. П. Город нашей славы трудовой: материал в помощь лекторам и пропагандистам / С. П. Люшин. - Волгоград : Волгогр. правда, 1967. $-30 \mathrm{c}$.

15. Люшин, С. П. Трудовой подвиг волгоградцев : Исторический очерк восстановления и развития города-героя, 1943-1962 / С. П. Люшин. - Волгоград : Волгогр. кн. изд-во, 1963. - 228 с.

16. Отчет и сведения облсовета Осовиахима о работе по разминированию и сбору трофеев за 1944 г. // ГАВО. - Ф. 2129. - Оп. 3. - Д. 28.

17. Редькина, О. Ю. Участие Сталинградской группы войск в санитарной очистке территории города и области после окончания Сталинградской битвы / О. Ю. Редькина, С. Ю. Пищулина // Память и время: влияние войн и вооруженных конфликтов XX в. на российское общество : сб. ст. Междунар. науч.-практ. конф. (Новороссийск, 12-15 сент. 2016 г.). - Пенза : Изд-во ПГУ, 2016. - С. 67-72.

18. Сведения райгорсоветов Осовиахима о ходе работ по сплошному разминированию местности и сбору оружия, акты приема разминированных территорий районов области, 1945 г. // ГАВО. Ф. 2129. - Оп. 3. - Д. 42.

19. Справка о работе облвоенкомата за 1943 г. // Центр документации новейшей истории Волгоградской области (ЦДНИВО). - Ф. 171. - Оп. 1. Д. 60.

20. Справки отдела и секретарей парторганизаций, начальников речного порта и железной дороги о восстановлении и работе железнодорожного и речного транспорта, о состоянии партийнополитической работы, февраль - август 1943 г. // ЦДНИВО. - Ф. 71. - Оп. 2. - Д. 125.
21. Сталинградская группа войск, Февраль май 1943 г. : Документы и материалы. - Волгоград : Издатель, 2004. - 264 с.

22. Сталинградский городской Комитет обороны в годы Великой Отечественной войны : Документы и материалы. - Волгоград : Издатель, 2003. $920 \mathrm{c}$.

23. Чадаев, Я. Е. Экономика СССР в годы Великой Отечественной войны (1941-1945) / Я. Е. Чадаев. - М. : Мысль, 1985. - 494 с.

\section{REFERENCES}

1. Vladimirova E.D., Golovina E.L. Stalingradskaya gruppa voysk: meropriyatiya po razminirovaniyu, 1943-1945 [Stalingrad Group of Troops: Measures on Mine Clearing. 1943-1945]. Problemy natsionalnoy bezopasnosti Rossii: uroki istorii $i$ vyzovy sovremennosti. 25 let bez Sovetskogo Soyuza: materialy Mezhdunar. nauch.-prosvet. konf., 27-31 maya 2016 g. [The Russian National Security Issues: Lessons of History and Modern Challenges. The 25 Years Without of the Soviet Union. Materials of the International Theoretical and Educational Conference, May 27-31, 2016]. Krasnodar, Traditsiya Publ., 2016, pp. 44-48.

2. Godovoy otchet o rabote vzvodov-minerov byvshikh v okkupatsii v rayonakh oblasti za $1946 \mathrm{~g}$. [The Annual Report about the Work of PlatoonsMiners Who Were in Occupation Districts of the Region in 1946]. Gosudarstvennyy arkhiv Volgogradskoy oblasti [State Archive of the Volgograd Region], F. 2129, Op. 3, D. 47.

3. Godovoy otchet ob ekspluatatsionnoy deyatelnosti NVRP za 1943 g. [Annual Report on Operational Activities of the LVSL in 1943]. Rossiyskiy gosudarstvennyy arkhiv ekonomiki [Russian State Archive of Economy], F. 9469, Op. 6, D. 47.

4. Golovina E.L., Gomanenko O.A., Usik B.G. Podgotovka spetsialistov po razminirovaniyu poley $\mathrm{i}$ postroek v yanvare - iyune 1943 goda [Training of Fields and Buildings Deminers in January-June, 1943]. Voennaya istoriya Rossii: problemy, poiski, resheniya: materialy III Mezhdunar. nauch. konf., posvyashch. 160-letiyu okonchaniya Krymskoy voyny 1853-1856 gg., Volgograd, 23-24 sent. 2016 g. $V 2$ ch. Ch. 2. [Military History of Russia: Problems, Searches, Solutions: Proceedings of the $3^{\text {rd }}$ International Academic Conference, Devoted to the $160^{\text {th }}$ Anniversary of the Crimean War of 1853-1856, Volgograd, September 23-24, 2016. In 2 Parts. Part 2]. Volgograd, Izd-vo VolGU, 2016, pp. 54-63.

5. Gomanenko O.A. Vosstanovlenie materialnotekhnicheskoy bazy rechnoy infrastruktury Nizhney Volgi v 1943 godu [Reconstruction of the Material and 
Technical Basis of the Lower Volga Transport Infrastructure in 1943]. Ekonomicheskaya istoriya Rossii: problemy, poiski, resheniya: ezhegodnik. Vyp. 10. [Economic History of Russia: Problems, Searches, Solutions: Yearbook. Iss. 10]. Moscow; Volgograd, Izd-vo VolGU, 2008, pp. 65-70.

6. Gomanenko O.A., Redkina O.Yu. Minnaya opasnost na Nizhney Volge v navigatsiyu 1943 goda [The Mine Threat in the Lower Volga in Navigation of 1943]. Problemy natsionalnoy bezopasnosti Rossii: uroki istorii i vyzovy sovremennosti. 25 let bez Sovetskogo Soyuza: materialy Mezhdunar. nauch.prosvet. konf., 27-31 maya 2016 g. [The Russian National Security Issues: Lessons of History and Modern Challenges. The 25 Years Without of the Soviet Union. Materials of the International Theoretical and Educational Conference, May 27-31, 2016]. Krasnodar, Traditsiya Publ., 2016, pp. 56-60.

7. Gomanenko O.A. Nizhnevolzhskoe rechnoe parokhodstvo v 1943 g. [The Low Volga River Steamship Line in 1943]. Ekonomicheskaya istoriya Rossii: problemy, poiski, resheniya: ezhegodnik. Vyp. 7 [Economic History of Russia: Problems, Searches, Solutions: Yearbook. Iss. 7]. Moscow; Volgograd, Izd-vo VolGU, 2005, pp. 91-95.

8. Dokladnye zapiski o formirovanii, sostoyanii operativno-sluzhebnoy i boevoy deyatelnosti istrebitelnogo batalona Ilovatskogo rayona, 19411944 gg. [Reports about Formation, Status of Operational and Combat Activities of the Fighting Battalion of the Ilovat District. 1941-1944]. Gosudarstvennyy arkhiv Volgogradskoy oblasti [State Archive of the Volgograd Region], F. 773, Op. 1, D. 31 .

9. Zagorulko M.M., Gomanenko O.A., Vladimirova E.D. Razyasnitelnaya rabota s naseleniem Stalingradskoy oblasti o pravilakh obrashcheniya so vzryvoopasnymi predmetami v 1943 godu [Explanatory Work with the Population of the Stalingrad Region on the Treatment of Explosive Objects in 1943]. Pamyat $i$ vremya: vliyanie voyn $i$ vooruzhennykh konfliktov XX v. na Rossiyskoe obshchestvo: sb. st. Mezhdunar. nauch.-prakt. konf. (g. Novorossiysk, 1215 sentyabrya $2016 \mathrm{~g}$.) [Memory and Time: Influence of Wars and Armed Conflicts of the $20^{\text {th }}$ Century on the Russian Society: Collection of Articles of the International Academic and Practical Conference (Novorossiysk, September 12-15, 2016)]. Penza, Izd-vo PGU, 2016, pp. 189-190.

10. Istoriya g. Stalingrada i oblasti v 19371953 gg. : Materialy k fakultativnomu kursu [History of Stalingrad and the Stalingrad Region in 1937-1953: Materials to a Facultative Course]. Volgograd, Volgogradskoe nauchnoe izd-vo, 2008.

11. Kuznetsova N.V. Vosstanovlenie zhilogo fonda Stalingrada v 1943-1945 godakh [Restoration of
Housing Stock of Stalingrad in 1943-1945]. Vestnik Volgogradskogo gosudarstvennogo universiteta. Seriya 4, Istoriya. Regionovedenie. Mezhdunarodnye otnosheniya [Science Journal of Volgograd State University. History. Area Studies. International Relations], 2003, iss. 8, pp. 12-19.

12. Kuznetsova N.V. Nizhnee Povolzhye v 1945 $1953 \mathrm{gg}$.: sotsialnye problemy poslevoennogo vosstanovleniya i razvitiya [The Lower Volga Region in 1945-1953: Social Problems of Post-War Restoration and Development]. Volgograd, Volgogradskoe nauchnoe izd-vo, 2010. $220 \mathrm{p}$.

13. Kuzmina E.V. Vosstanovlenie Stalingrada: 1943-1950 [Restoration of Stalingrad: 1943-1950]. Volgograd, Izdatel Publ., 2002. 141 p.

14. Lyushin S.P. Gorod nashey slavy trudovoy: material $v$ pomoshch lektoram i propagandistam [City of Our Labour Glory: Materials for Lecturers and Propagandists]. Volgograd, Volgogr. pravda Publ., $1967.30 \mathrm{p}$.

15. Lyushin S.P. Trudovoy podvig volgogradtsev: Istoricheskiy ocherk vosstanovleniya i razvitiya goroda-geroya, 1943-1962 [Labour Feat of Volgograd Citizens. Historical Sketch of Restoration and Development of the Hero City. 1943-1962]. Volgograd, Volgogradskoe knizhnoe izd-vo, 1963. 228 p.

16. Otchet i svedeniya oblsoveta Osoviakhima o rabote po razminirovaniyu i sboru trofeev za $1944 \mathrm{~g}$. [The Report and Data of the Regional Council of Osaviachim about the Work on Demining and Collecting Trophies in 1944]. Gosudarstvennyy arkhiv Volgogradskoy oblasti [State Archive of the Volgograd Region], F. 2129, Op. 3, D. 28.

17. Redkina O.Yu., Pishchulina S.Yu. Uchastie Stalingradskoy gruppy voysk v sanitarnoy ochistke territorii goroda i oblasti posle okonchaniya Stalingradskoy bitvy [Participation of the Stalingrad Group of Troops in Sanitary Processing of the City and Region after the Battle of Stalingrad]. Pamyat $i$ vremya: vliyanie voyn $i$ vooruzhennykh konfliktov $X X$ v. na rossiyskoe obshchestvo: sb. st. Mezhdunar. nauch.-prakt. konf. (Novorossiysk, 12-15 sent. 2016 g.) [Memory and Time: Influence of Wars and Armed Conflicts of the $20^{\text {th }}$ Century on the Russian Society: Collection of Articles of the International Academic and Practical Conference (Novorossiysk, September 12-15, 2016)]. Penza, Izd-vo PGU, 2016, pp. 67-72.

18. Svedeniya raygorsovetov Osoviakhima o khode rabot po sploshnomu razminirovaniyu mestnosti i sboru oruzhiya, akty priema razminirovannykh territoriy rayonov oblasti, $1945 \mathrm{~g}$. [Data of the Osoviahim District Councils about Full Demining of the Area and about Collecting Weapons, Acts of Receiving Mined Areas of the Regional Districts, 1945]. Gosudarstvennyy arkhiv Volgogradskoy oblasti 
[State Archive of the Volgograd Region], F. 2129, Op. 3, D. 42.

19. Spravka o rabote oblvoenkomata za $1943 \mathrm{~g}$. [Information about the Work of the Regional Military Enlistment Office for 1943]. Tsentr dokumentatsii noveyshey istorii Volgogradskoy oblasti [Center for Documentation of the Modern History of the Volgograd Region], F. 171, Op. 1, D. 60.

20. Spravki otdela i sekretarey partorganizatsiy, nachalnikov rechnogo porta i zheleznoy dorogi o vosstanovlenii i rabote zheleznodorozhnogo i rechnogo transporta, o sostoyanii partiynopoliticheskoy raboty, fevral - avgust $1943 \mathrm{~g}$. [References of the Department and Secretaries of Party Organizations, Chiefs of the River Port and Railway about the Restoration and Operation of Railway and River Transport, the State of Party Political Work,
February-August 1943]. Tsentr dokumentatsii noveyshey istorii Volgogradskoy oblasti [Center for Documentation of the Modern History of the Volgograd Region], F. 71, Op. 2, D. 125.

21. Stalingradskaya gruppa voysk, Fevral may 1943 g.: Dokumenty i materialy [Stalingrad Group of Forces, February-May 1943: Documents and Materials]. Volgograd, Izdatel Publ., 2004. 264 p.

22. Stalingradskiy gorodskoy Komitet oborony $v$ gody Velikoy Otechestvennoy voyny: Dokumenty $i$ materialy [Stalingrad City Defense Committee during the Great Patriotic War: Documents and Materials]. Volgograd, Izdatel Publ., 2003. 920 p.

23. Chadaev Ya.E. Ekonomika SSSR v gody Velikoy Otechestvennoy voyny (1941-1945) [Economy of the USSR During the Great Patriotic War (1941-1945)]. Moscow, Mysl Publ., 1985. 494 p.

\section{Information about the Author}

Olesya A. Gomanenko, Candidate of Sciences (History), Associate Professor, Department of Social Work and Pedagogy, Volgograd State University, Prosp. Universitetsky, 100, 400062 Volgograd, Russian Federation, gomanenko@volsu.ru, gomanenko.olesya@mail.ru, https://orcid.org/0000-0001-9178-1145

\section{Информация об авторе}

Олеся Александровна Гоманенко, доцент, кандидат исторических наук, доцент кафедры социальной работы и педагогики, Волгоградский государственный университет, просп. Университетский, 100, 400062 г. Волгоград, Российская Федерация, gomanenko@volsu.ru, gomanenko.olesya@mail.ru, https://orcid.org/0000-0001-9178-1145 